\title{
Use of conventional taxonomy, electrophoretic karyotyping and DNA-DNA hybridization for the classification of fermentative apiculate yeasts
}

\author{
Ann Vaughan-Martini, Paola Angelini and Gianluigi Cardinali
}

Industrial Yeasts Collection (DBVPG), Dipartimento di Biologia Vegetale, Università di Perugia, Sez. Microbiologia Applicata, Borgo XX Giugno 74, 06121 Perugia, Italy

\author{
Author for correspondence: Ann Vaughan-Martini. Tel: +39075 585 6479. Fax: + 390755856470 . \\ e-mail: avaughan@unipg.it
}

\begin{abstract}
A taxonomic study was conducted that considered strains of the genera Hanseniaspora/Kloeckera held in the Industrial Yeasts Collection (DBVPG) of the Dipartimento di Biologia Vegetale of the Università di Perugia, Italy. Standard phenotypic as well as molecular criteria were considered in a effort to revisit the classification of these strains, some of which have been in the collection for about $\mathbf{5 0}$ years. Results of salient physiological tests showed that some of the DBVPG and type strains could not be identified by current taxonomic keys. Electrophoretic karyotypes were identical for some species, with the type strains of the seven accepted species showing only five distinct chromosomal patterns. DNA-DNA hybridization analyses, using a nonradioactive dot-blot technique, allowed for the distinction of taxa. The taxonomic implications of these results are discussed.
\end{abstract}

Keywords: Hanseniaspora, conventional and molecular taxonomy, non-radioactive dot-blot DNA reassociation, pulsed-field gel electrophoresis

\section{INTRODUCTION}

The genus Hanseniaspora was created when Klöcker (1912) described the species Hanseniaspora valbyensis, although studies of fermenting, apiculate yeasts began much earlier, in 1870, when Reess designated a nonsporulating strain as Saccharomyces apiculatus (Reess, 1870). The years that followed saw many different treatments of the classification and nomenclature of this group of yeasts due to problems experienced by investigators in the perception of a sexual cycle.

In spite of the absence of sporulation, Reess (1870) probably included $S$. apiculatus in a perfect genus because of its ability to ferment grape must, a trait far from universal in yeasts. It would not be until 28 years later that Beijerinck (1898) observed sporulation, with a direct transformation of the vegetative cell into an ascus containing, according to the author, between four and six ascospores. At that time, it was also pointed out that $S$. apiculatus tended to lose sexual capacity with prolonged cultivation. Lindner (1903) also observed a sexual cycle for this species and designated the genus Hansenia, for apiculate yeasts that form spores. Zikes (1911), however, was unable to

Abbreviation: PFGE, pulsed-field gel electrophoresis. confirm sporulation in some strains of Hansenia and therefore assigned it to an anamorphic taxon of fermenting, apiculate yeasts. He then proposed the generic name Hanseniaspora for the perfect taxa. Finally, after a series of incongruences in nomenclature, Hansenia was replaced by the generic name Kloeckeria and then Kloeckera (Janke, 1928).

Over the years, additional apiculate yeasts were described and Hanseniaspora has grown from the original single species described in the first edition of the monograph The Yeasts: a Taxonomic Study (Lodder \& Kreger-van Rij, 1952) to the present six recognized taxa in the fourth edition (Smith, 1998a). Over the same time-period, the genus Kloeckera has been reduced to a single species, Kloeckera lindneri (Kloecker) Janke (Janke, 1928; Smith, 1998b), since studies of molecular taxonomy have demonstrated a high genomic relationship between all of the teleomorphic and anamorphic forms (Smith et al., 1977; Meyer et al., 1978) except for Kloeckera lindneri.

The present study set out to reinvestigate some strains of the DBVPG Industrial Yeasts Collection classified as the most common species of Hanseniaspora/ Kloeckera involved in grape-must fermentation in Italy: Hanseniaspora guilliermondii with its imperfect form Kloeckera apis, Hanseniaspora osmophila (ana- 
morphs Kloeckera corticis and Kloeckera magna), Hanseniaspora uvarum (Kloeckera apiculata) and Hanseniaspora vineae with Kloeckera africana. The DBVPG collection holds over 150 strains belonging to this group that have been isolated from various substrates over a period of about 50 years. Since the separation of these taxa is sometimes difficult, especially in the absence of a sexual cycle, it was deemed necessary to confirm the original designations of some of these strains by employing the most recent conventional criteria (Smith, 1998a, b) together with methods of molecular taxonomy.

\section{METHODS}

Organisms. The strains studied are listed in Table 1. Type strains of the perfect and imperfect species were kindly provided by the yeast division of the Centraalbureau voor Schimmelcultures (CBS), Delft, The Netherlands.

Physiological studies. Growth responses on sole carbon and nitrogen sources, as well as resistance to cycloheximide (actidione), were determined in liquid medium on a roller drum at $25^{\circ} \mathrm{C}$ by using the methods described by Yarrow (1998). Maximum growth temperatures were determined by using static cultures containing YEPG (1\% yeast extract,
$1 \%$ peptone, $2 \%$ glucose) equilibrated in a water bath. An effort to induce a sexual cycle was made following current recommendations (Smith, 1998a).

\section{Preparation and analysis of nuclear DNA}

Pulsed-field gel electrophoresis (PFGE). Intact chromosomal DNA for PFGE was prepared as reported previously (Cardinali et al., 1995). Gels composed of $1 \%$ agarose (type II-A, medium EEO; Sigma) were analysed using a CHEF Mapper or DRII (Bio-Rad) with $0.5 \times \mathrm{TBE}$ buffer. A temperature of $12-15^{\circ} \mathrm{C}$ was maintained throughout the runs and the parameters of the electrophoresis are described in the figure legends.

Hybridization experiments. DNA extraction and hydroxyapatite (HTP; Bio-Rad) purification were performed according to the protocol proposed by Cardinali et al. (2000). DNA-DNA hybridization experiments were performed using a dot-blot procedure where probe DNA was labelled using the ECL-Direct non-radioactive procedure (Amersham) following the manufacturer's instructions. Prehybridization, hybridization and high-stringency washes $(0.5 \% \mathrm{NaCl})$ were all carried out at $42{ }^{\circ} \mathrm{C}$.

Densitometric analysis of the DNA-DNA hybridizations. X-ray film (Kodak X-OMAT; Sigma) was exposed for 1, 2, 5 or $15 \mathrm{~min}$ according to the intensity of the signal. Only non-saturated films were subjected to further analysis.

Table 1. DBVPG isolates examined in the present study

\begin{tabular}{|c|c|c|c|}
\hline Strain & Species or original epithet & Source & $\begin{array}{r}\text { Date of } \\
\text { deposit }\end{array}$ \\
\hline 3062 & Hanseniaspora apuliensis Castelli & Grape must; Israel & 1950 \\
\hline 3094 & Kloeckera apiculata & Wine; Trentino, Italy & 1951 \\
\hline 3096 & Kloeckera magna & Sweet filtered wine; Brindisi, Italy & 1951 \\
\hline 3272 & Kloeckera apiculata & Grape must; Calabria, Italy & 1952 \\
\hline 3280 & Kloeckera apiculata & Soil; The Netherlands & 1952 \\
\hline 3298 & Kloeckera africana & Wine; Capoterra (Sardinia), Italy & 1952 \\
\hline 3447 & Kloeckera apiculata & Milk; Perugia, Italy & 1955 \\
\hline 3539 & Kloeckera apiculata & Flowers; Perugia, Italy & 1955 \\
\hline 3542 & Kloeckera apiculata & Soil; Puerto Lapiche, Spain & 1955 \\
\hline 3543 & Kloeckera magna & $\begin{array}{l}\text { Grapes; Cerro del Moro (La } \\
\text { Mancha), Spain }\end{array}$ & 1955 \\
\hline 3582 & Kloeckera apiculata & Grapes; Fuen Mayor (Rioja), Spain & 1956 \\
\hline 4033 & Kloeckera magna & Cavern; Italy & 1963 \\
\hline 4059 & Kloeckera magna & Grape must; Slovenia & 1968 \\
\hline 4159 & Kloeckera magna & Grape must; Slovenia & 1968 \\
\hline 4160 & Kloeckera magna & Grape must; Slovenia & 1968 \\
\hline 4351 & Kloeckera apiculata & Sea water; Italy & 1994 \\
\hline $6717^{\mathrm{T}}$ & Pseudosaccharomyces apiculatus (Reess) Klöcker & Unknown & 1993 \\
\hline $6718^{\mathrm{T}}$ & Hanseniaspora uvarum (Niehaus) Shehata et al. & Muscatelle grapes; Ukraine & 1990 \\
\hline $6774^{\mathrm{T}}$ & Hanseniaspora valbyensis Klöcker & Soil; Denmark & 1993 \\
\hline $6790^{\mathrm{T}}$ & Kloeckera apis Lavie ex M. T. Smith et al. & Trachea of bee; France & 1993 \\
\hline $6791^{\mathrm{T}}$ & Kloeckera corticis (Klöcker) Janke & Bark of tree; Denmark & 1993 \\
\hline $6792^{\mathrm{T}}$ & Kloeckera africana (Klöcker) Janke & Soil; Algeria & 1993 \\
\hline $6793^{\mathrm{T}}$ & Kloeckera japonica Saito \& Otani & Sap of tree; Japan & 1993 \\
\hline $6794^{\mathrm{T}}$ & Pseudosaccharomyces javanicus Klöcker & Soil; Java & 1993 \\
\hline $6795^{\mathrm{T}}$ & Hanseniaspora osmophila (Niehaus) Phaff et al. ex M. Th. Smith & Ripe Reisling grapes; Germany & 1993 \\
\hline $6796^{\mathrm{T}}$ & Hanseniaspora guilliermondii Pijper & Infected nail; South Africa & 1993 \\
\hline $6797^{\mathrm{T}}$ & Hanseniaspora vineae van der Walt \& Tscheuschner & Soil of vineyard; South Africa & 1993 \\
\hline $6798^{\mathrm{T}}$ & Hanseniaspora occidentalis M. T. Smith & Soil; West Indies & 1993 \\
\hline $7132^{\mathrm{T}}$ & Kloeckera lindneri (Klöcker) Janke & Soil; Java & 1998 \\
\hline
\end{tabular}


A calibration curve was obtained by plotting the values of serial probe dilutions against the corresponding signals expressed as grey levels (according to a 256-level system). A regression equation was used to calculate the reassociation level of each sample. Video densitometric analysis was carried out using the free-domain software NIH IMAGE $1.62 \mathrm{~b}$ and densitometric data were processed with KALEIDA GRAPH (Synergy Software).

\section{RESULTS AND DISCUSSION}

\section{Physiological reactions}

A summary of salient phenotypic characteristics (Table 2) shows that most of the DBVPG strains repeated the assimilative patterns observed at the time of the original species designation. According to the most recent criteria for the classification of the genera Hanseniaspora/Kloeckera (Smith, 1998a, b), all strains originally classified as Kloeckera apiculata, as well as the type strains of Hanseniaspora guilliermondii/ Kloeckera apis and Hanseniaspora uvarum/Kloeckera apiculata, were unable to utilize sucrose or maltose as sole carbon sources, whereas those designated as Kloeckera africana or Kloeckera magna, together with the type strains of Kloeckera africana $\left(6792^{\mathrm{T}}\right)$ and Kloeckera corticis $\left(6791^{\mathrm{T}}\right)$, showed positive results on one or both of those sugars. On the other hand, the type strains of Hanseniaspora osmophila $\left(6795^{\mathrm{T}}\right)$ and

Table 2. Comparison of physiological reactions and electrophoretic profiles of selected strains of Hanseniaspora/Kloeckera

\begin{tabular}{|c|c|c|c|c|c|c|c|c|c|}
\hline \multirow[t]{2}{*}{ Strain } & \multicolumn{3}{|c|}{ Assimilation* } & \multicolumn{4}{|c|}{ Growth } & \multicolumn{2}{|c|}{ Apparent phenotype } \\
\hline & MAL & SUC & 2KG & $100 \mathrm{ACT} \dagger$ & $30^{\circ} \mathrm{C}$ & $35^{\circ} \mathrm{C}$ & $37^{\circ} \mathrm{C}$ & Physiology & CHEF \\
\hline 3062 & - & - & + & + & + & + & + & G & $\mathrm{G} / \mathrm{U}$ \\
\hline 3094 & - & - & + & + & + & - & - & U & $\mathrm{G} / \mathrm{U}$ \\
\hline 3096 & + & - & + & - & + & - & - & $\mathrm{Os} / \mathrm{U}$ & $\mathrm{Os} / \mathrm{Vi}$ \\
\hline 3272 & - & - & + & + & + & - & - & U & $\mathrm{G} / \mathrm{U}$ \\
\hline 3280 & - & - & + & + & + & - & - & $\mathrm{U}$ & $\mathrm{G} / \mathrm{U}$ \\
\hline 3298 & + & \pm & - & - & + & - & - & Os & $\mathrm{Os} / \mathrm{Vi}$ \\
\hline 3447 & - & - & + & $\mathrm{ND}$ & + & + & - & $\mathrm{U}$ & $\mathrm{G} / \mathrm{U}$ \\
\hline 3539 & - & - & + & $\mathrm{ND}$ & + & - & - & U & $\mathrm{G} / \mathrm{U}$ \\
\hline 3542 & - & - & + & $\mathrm{ND}$ & + & - & - & $\mathrm{U}$ & $\mathrm{G} / \mathrm{U}$ \\
\hline 3543 & \pm & \pm & - & - & + & - & - & Os & $\mathrm{Os} / \mathrm{Vi}$ \\
\hline 3582 & - & - & + & + & + & - & - & $\mathrm{U}$ & $\mathrm{G} / \mathrm{U}$ \\
\hline 4033 & + & \pm & - & - & + & - & - & Os & $\mathrm{Os} / \mathrm{Vi}$ \\
\hline 4059 & + & \pm & + & $\mathrm{ND}$ & + & - & - & $\mathrm{Os} / \mathrm{U}$ & $\mathrm{Os} / \mathrm{Vi}$ \\
\hline 4159 & + & \pm & - & $\mathrm{ND}$ & + & + & + & $\mathrm{G} / \mathrm{Vi}$ & $\mathrm{Os} / \mathrm{Vi}$ \\
\hline 4160 & + & - & - & $\mathrm{ND}$ & + & - & - & Os & $\mathrm{Os} / \mathrm{Vi}$ \\
\hline 4351 & - & - & + & + & + & - & - & $\mathrm{U}$ & $\mathrm{G} / \mathrm{U}$ \\
\hline $6717^{\mathrm{T}}$ & - & - & + & + & - & - & - & $\mathrm{U} / \mathrm{Va}$ & $\mathrm{G} / \mathrm{U}$ \\
\hline $6718^{\mathrm{T}}$ & - & - & + & + & + & - & - & $\mathrm{U}$ & $\mathrm{G} / \mathrm{U}$ \\
\hline $6774^{\mathrm{T}}$ & - & - & - & + & + & - & - & $\mathrm{L} / \mathrm{Va}$ & $\mathrm{Va}$ \\
\hline $6790^{\mathrm{T}}$ & - & - & + & + & + & + & + & $\mathrm{G}$ & $\mathrm{G} / \mathrm{U}$ \\
\hline $6791^{\mathrm{T}}$ & + & - & - & - & + & - & - & Os & $\mathrm{Os} / \mathrm{Vi}$ \\
\hline $6792^{\mathrm{T}}$ & + & \pm & - & - & + & + & - & $\mathrm{Vi}$ & $\mathrm{Os} / \mathrm{Vi}$ \\
\hline $6793^{\mathrm{T}}$ & - & - & - & + & + & - & - & $\mathrm{L}$ & $\mathrm{Va}$ \\
\hline $6794^{\mathrm{T}}$ & - & + & - & ND & + & - & - & Oc & Oc \\
\hline $6795^{\mathrm{T}}$ & - & - & + & - & + & - & - & $?$ & $\mathrm{Os} / \mathrm{Vi}$ \\
\hline $6796^{\mathrm{T}}$ & - & - & + & + & + & + & + & G & $\mathrm{G} / \mathrm{U}$ \\
\hline $6797^{\mathrm{T}}$ & - & - & - & - & + & + & + & $?$ & Os/Vi \\
\hline $6798^{\mathrm{T}}$ & - & + & - & ND & + & - & - & $\mathrm{Oc}$ & $\mathrm{Oc}$ \\
\hline $7132^{\mathrm{T}}$ & - & - & - & ND & - & - & - & Va? & $\mathrm{L}$ \\
\hline
\end{tabular}

* Assimilation of maltose (MAL), sucrose (SUC) and 2-ketogluconate (2KG) was tested.

$\uparrow$ Resistance to 100 p.p.m. cycloheximide (actidione).

$\$$ Phenotypes are indicated as G (Hanseniaspora guilliermondii), L (Kloeckera lindneri), Oc (Hanseniaspora occidentalis), Os (Hanseniaspora osmophila), U (Hanseniaspora uvarum), Va (Hanseniaspora valbyensis) and Vi (Hanseniaspora vineae).

$\S$ Electrophoretic karyotype obtained by PFGE.

ND, Not done. 
Hanseniaspora vineae $\left(6797^{\mathrm{T}}\right)$ were not able to use either sugar, even though, according to current keys, maltose assimilation should be positive for these species (Smith, 1998a). Although all strains of Hanseniaspora guilliermondii/Kloeckera apis and Hanseniaspora uvarum/Kloeckera apiculata showed growth on 2-ketogluconate as expected, three other strains originally designated as Hanseniaspora osmophila or Kloeckera magna $\left(3096,4059\right.$ and $\left.6795^{\mathrm{T}}\right)$ were also unexpectedly able to utilize this carbon source. Finally, temperature reactions at 37 and $30{ }^{\circ} \mathrm{C}$ did not always correspond to current taxonomic indications (Smith, 1998a, b). As a consequence of these physiological variations, some of the type and DBVPG strains had to be assigned an 'apparent phenotype' (Table 2) that was different from the original species designation.

The physiological inconsistencies observed in this study have also been encountered by previous authors. Even though Meyer and coworkers divided Hanseniaspora valbyensis into two separate species (Meyer et al., 1977), with strains of Hanseniaspora guilliermondii characterized by the formation of four spores per ascus and the ability to grow at $37^{\circ} \mathrm{C}$ and to assimilate 2ketogluconate as a sole carbon source, Phaff (1970) had already noted that some four-spored strains gave negative reactions to some of these tests. These observations, together with the results of this and another study of strains of Hanseniaspora/Kloeckera (Boekhout et al., 1994), renew the reservations regarding the validity of physiological criteria as a basis for species designations. One could speculate either that these reactions are not universal for all strains of a species or that they are not stable over time. It is well known that the shortcomings of the use of physiological tests for the distinction of taxa derive from the fact that many of the systems used for the long-term storage of strains can lead to point mutations (Scheda \& Yarrow, 1966, 1968; Stahl \& Esser, 1979a, b). Since the nucleotide base sequences that make up the genes that control many of these reactions often represent a minimal part of the genome (Price et al., 1978), minor modifications could result in significant changes in species designations based on these criteria. For this reason, in the last 30 years, taxonomic studies have been integrated with tests based on more stable parameters such as the comparison of cellular macromolecules, particularly DNA and RNA (Kurtzman \& Phaff, 1987; Phaff, 1989; James et al., 1997; Kurtzman \& Robnett, 1998).

\section{Electrophoretic karyotypes}

The comparison of the electrophoretic karyotypes of unknown cultures against those of type strains can sometimes give a confirmation of identifications obtained by conventional taxonomic methods (Vaughan-Martini et al., 1999). However, in this investigation, it was seen that this type of analysis cannot always be useful for the distinction of strains belonging to the genera Hanseniaspora/Kloeckera, as

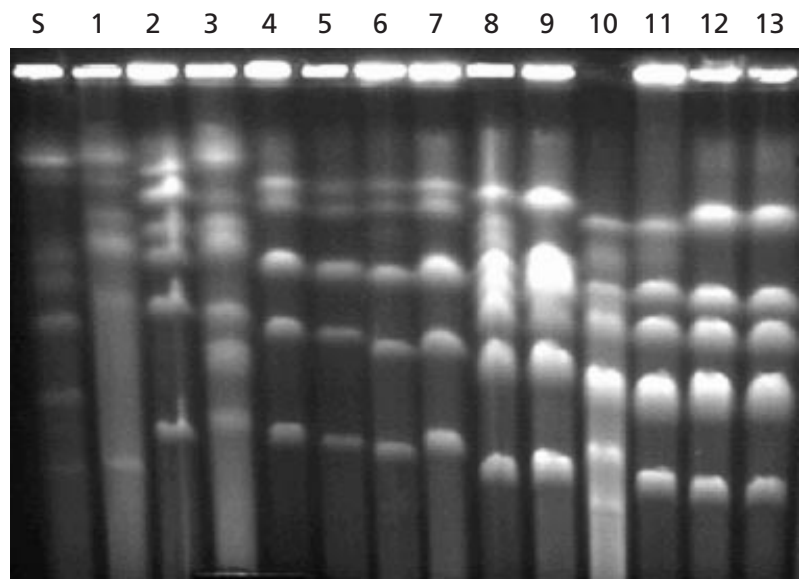

Fig. 1. Electrophoretic karyotypes of the type strains of Hanseniaspora and Kloeckera. Lanes: S, Pichia canadensis standard (referred to as Hansenula wingei), obtained from BioRad; 1, Kloeckera lindneri DBVPG $7132^{\top}$; 2, Hanseniaspora occidentalis DBVPG $6798^{\top}$; 3, Kloeckera javanicus DBVPG $6794^{\top}$; 4, Hanseniaspora vineae DBVPG $6797^{\top}$; 5, Kloeckera africana DBVPG $6792^{\top}$; 6, Hanseniaspora osmophila DBVPG $6795^{\top} ; 7$, Kloeckera corticis DBVPG $6791^{\top} ; 8$, Kloeckera japonica DBVPG $6793^{\top}$; 9, Hanseniaspora valbyensis DBVPG $6774^{\top}$; 10, Hanseniaspora guilliermondii DBVPG $6796^{\top} ; 11$, Kloeckera apis DBVPG $6790^{\top} ; 12$, Hanseniaspora uvarum DBVPG $6718^{\top} ; 13$, Kloeckera apiculata DBVPG $6717^{\top}$. Electrophoresis conditions: CHEF DRII; $72 \mathrm{~h} ; 60 \rightarrow 420$ s switch, $4.5 \mathrm{~V} \mathrm{~cm}^{-1}$.

only five distinct profiles were observed for the type strains of the seven currently accepted species (Fig. 1). Two chromosomal patterns were each shared by two species: the karyotype of Hanseniaspora guilliermondii was identical to that of Hanseniaspora uvarum (strains $6796^{\mathrm{T}}, 6790^{\mathrm{T}}, 6718^{\mathrm{T}}$ and $6717^{\mathrm{T}}$; lanes $10-13$ ), while Hanseniaspora osmophila and Hanseniaspora vineae (strains $6797^{\mathrm{T}}, 6792^{\mathrm{T}}, 6795^{\mathrm{T}}$ and $6791^{\mathrm{T}}$; lanes $4-7$ ) also had the same profiles. These similarities could not be overcome even when the conditions of electrophoresis were modified radically (as shown in Figs 2 and 3). Distinctive profiles were seen only for the type strain of Kloeckera lindneri $\left(7132^{\mathrm{T}}\right.$; Fig. 1, lane 1) and for the perfect/imperfect pairs Hanseniaspora valbyensis/ Kloeckera japonica $\left(6793^{\mathrm{T}}\right.$ and $6774^{\mathrm{T}}$; Fig. 1, lanes 8 and 9) and Hanseniaspora occidentalis/Kloeckera javanica $\left(6798^{\mathrm{T}}\right.$ and $6794^{\mathrm{T}}$; Fig. 1, lanes 2 and 3). Nevertheless, the apparent affinities observed between the species Hanseniaspora guilliermondii and Hanseniaspora uvarum or between Hanseniaspora osmophila and Hanseniaspora vineae are not in agreement with extensive studies of DNA reassociation, which demonstrated the presence of six distinct species in Hanseniaspora with reciprocal base sequence differences normally exceeding 80\% (Meyer et al., 1977, 1978; Smith et al., 1977). These separations were also confirmed by the DNA hybridizations performed in this study (Table 3), as well as by three separate investigations considering 26S rDNA sequences (Yamada et al., 1992a; Boekhout et al., 1994; Kurtzman \& Robnett, 1998). 
Table 3. Comparative percentage DNA-DNA hybridization among the type strains of the genera Hanseniaspora/Kloeckera

Values in bold were obtained in the present study. Other values were taken from Smith et al. (1977) and Meyer et al. (1978) and represent measurements using the same strains or, in the case of values in square brackets, different strains of the same species. H., Hanseniaspora; $K$.,

Kloeckera.

\begin{tabular}{|c|c|c|c|c|c|c|c|}
\hline \multirow[t]{2}{*}{ Strain } & \multicolumn{7}{|c|}{ Source of probe DNA } \\
\hline & 2 & 3 & 5 & 8 & 10 & 11 & 13 \\
\hline 1. H. uvarum $6717^{*}$ & 90, 100 & 32, [11] & 20, 14 & 4 & 3 & 18 & $\mathbf{0}$ \\
\hline 2. H. uvarum $6718^{\mathrm{T}}$ & $\mathbf{1 0 0}, 100$ & 33, [15] & 14,10 & $4,[15]$ & $\mathbf{0},[5]$ & $\mathbf{1 5},[10]$ & $\mathbf{0}$ \\
\hline 3. H. guilliermondii $6790 *$ & 4, 30 & 100,100 & $\mathbf{1 4}, 11$ & 0 & 2 & 17 & $\mathbf{0}$ \\
\hline 4. H. guilliermondii $6796^{\mathrm{T}}$ & $\mathbf{1 0}, 27$ & $\mathbf{8 1}, 100$ & 26, 19 & 1 & $\mathbf{0}$ & 25 & $\mathbf{0}$ \\
\hline 5. H. valbyensis $6774^{\mathrm{T}}$ & 22,20 & 23, [13] & 100,100 & 5 & 4 & 12 & $\mathbf{0}$ \\
\hline 6. H. valbyensis $6793^{*}$ & 11, 27 & 24, [10] & 68,100 & 8 & 6 & 9 & $\mathbf{0}$ \\
\hline 7. H. osmophila $6791^{*}$ & $\mathbf{9}, 1$ & 18 & $\mathbf{1 1},[12]$ & $\mathbf{9 8}, 85$ & 23,56 & $12,[15]$ & $\mathbf{0}$ \\
\hline 8. H. osmophila $6795^{\mathrm{T}}$ & 15,13 & 20 & 18 & $\mathbf{1 0 0}, 100$ & 18,60 & 17 & $\mathbf{0}$ \\
\hline 9. H. vineae $6792 *$ & 9 & 18 & $\mathbf{1 5},[5]$ & 36, 46 & $\mathbf{9 9 ,}, 93$ & 20, $[8]$ & $\mathbf{0}$ \\
\hline 10. H. vineae $6797^{\mathrm{T}}$ & $\mathbf{0}, 10$ & $\mathbf{2 0},[12]$ & $12,[13]$ & 35, [38] & $\mathbf{1 0 0}, 100$ & $12,[11]$ & $\mathbf{0}$ \\
\hline 11. H. occidentalis $6798^{\mathrm{T}}$ & $<1$ & $15,[7]$ & $\mathbf{1 0}, 11$ & $6,[16]$ & $\mathbf{0}$ & $100,[82]$ & $\mathbf{0}$ \\
\hline 12. H. occidentalis $6794^{*}$ & 2 & $15,[14]$ & 25, [9] & $\mathbf{1 4}, 19$ & 21 & $\mathbf{7 4},[100]$ & $\mathbf{0}$ \\
\hline 13. K. lindneri $7132^{\mathrm{T}}$ & $<1$ & $\mathbf{0}$ & 9 & $\mathbf{0}$ & $\mathbf{0}$ & $\mathbf{0}$ & 100 \\
\hline
\end{tabular}

* Type strain of the corresponding anamorph.

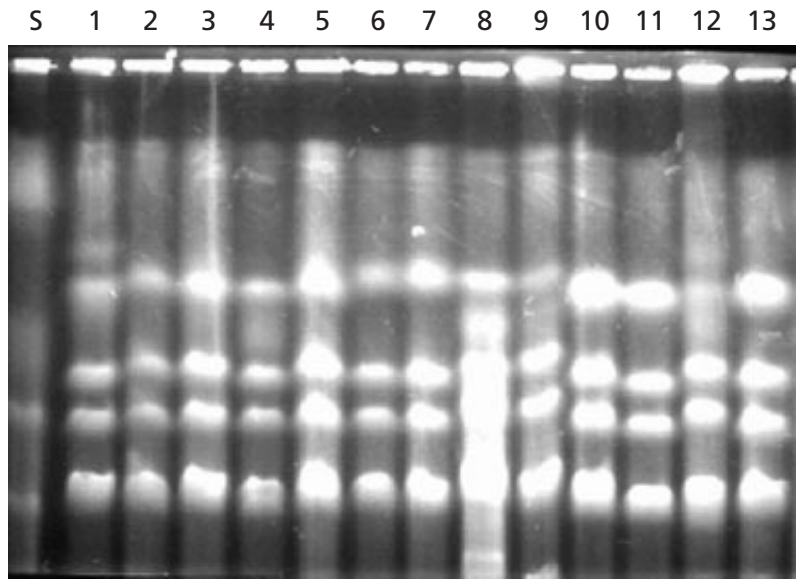

Fig. 2. Electrophoretic karyotypes of selected DBVPG strains related to Hanseniaspora guilliermondii or Hanseniaspora uvarum. Lanes: S, Pichia canadensis standard (referred to as Hansenula wingei), obtained from Bio-Rad; 1-6, Hanseniaspora uvarum strains DBVPG 4351, DBVPG 3542, DBVPG 3539, DBVPG 3272, DBVPG 3094 and DBVPG 6718 ${ }^{\top} ; 7$, Kloeckera apiculata DBVPG $6717^{\top} ; 8$, Hanseniaspora guilliermondii DBVPG $6796^{\top} ; 9$, Kloeckera apis DBVPG $6790^{\top} ; 10$, Hanseniaspora uvarum DBVPG 3582; 11, Hanseniaspora uvarum DBVPG 3280; 12, Hanseniaspora guilliermondii DBVPG 3062; 13, Hanseniaspora uvarum DBVPG 3447. Electrophoresis conditions: CHEF Mapper; $72 \mathrm{~h}$; $120^{\circ}$ angle; $60 \rightarrow 420$ s switch, $4.5 \mathrm{~V} \mathrm{~cm}^{-1}$.

The presence of similar or even identical electrophoretic karyotypes for different species is not new. A well-documented example can be seen in the four taxa of the sensu stricto complex of the genus Saccharo-

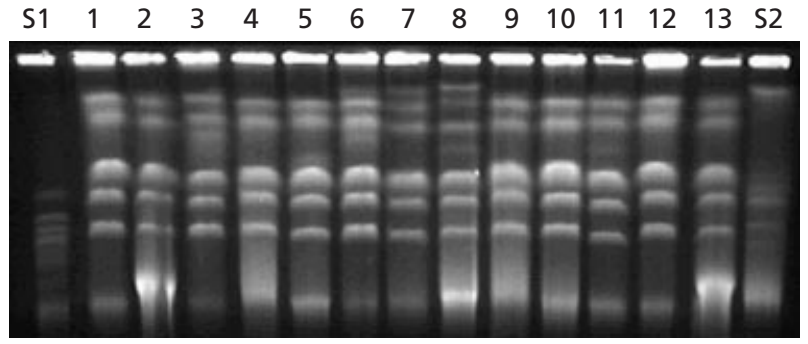

Fig. 3. Electrophoretic karyotypes of selected DBVPG strains related to Hanseniaspora osmophila or Hanseniaspora vinae. Lanes: S1, Saccharomyces cerevisiae standard; 1, Hanseniaspora vineae DBVPG $6797^{\top} ; 2$, Kloeckera africana DBVPG $6792^{\top} ; 3-5$, Hanseniaspora osmophila strains DBVPG 4033, DBVPG 4159 and DBVPG 3543; 6, Hanseniaspora vineae DBVPG 4160; 7, Hanseniaspora osmophila DBVPG 4059; 8, Hanseniaspora vineae DBVPG 3298; 9, Hanseniaspora vineae DBVPG 3096; 10, Kloeckera corticis DBVPG $6791^{\top} ; 11$, Hanseniaspora osmophila DBVPG $6795^{\top}$; 12, Hanseniaspora vineae DBVPG $6797^{\top}$; 13, Kloeckera africana DBVPG $6792^{\top}$; S2, Pichia canadensis standard (referred to as Hansenula wingei). Standards were obtained from Bio-Rad. Electrophoresis conditions: CHEF DRII; $56 \mathrm{~h} ; 500 \mathrm{~s}$ switch, $3 \mathrm{~V} \mathrm{~cm}^{-1}$.

myces, where it is difficult to differentiate species solely on the basis of chromosomal profiles (VaughanMartini et al., 1993). As a result, additional molecular analysis such as DNA-DNA hybridization is necessary for a clear distinction of taxa.

When the electrophoretic karyotypes of the DBVPG strains under study were compared with the patterns obtained for the type strains (Figs 2 and 3), it was not 
Table 4. Percentage DNA-DNA hybridization between type and other strains of the genera Hanseniaspora/Kloeckera

For explanations of the different phenotypes, see footnote to Table 2 . Values over $70 \%$ are in bold. H., Hanseniaspora; K., Kloeckera.

\begin{tabular}{|c|c|c|c|c|c|c|c|c|c|}
\hline \multirow[b]{2}{*}{ Strain } & \multicolumn{2}{|c|}{ Phenotype } & \multicolumn{7}{|c|}{ Source of probe DNA } \\
\hline & Physiology & CHEF & $\begin{array}{c}H . \\
\text { uvarum } \\
\text { 6718 }^{\mathrm{T}}\end{array}$ & $\begin{array}{l}\text { H. guilliermondii } \\
6790 *\end{array}$ & $\begin{array}{c}\text { H. valbyensis } \\
6774^{\mathrm{T}}\end{array}$ & $\begin{array}{c}\text { H. osmophila } \\
6795^{\mathrm{T}}\end{array}$ & $\begin{array}{c}\text { H. vineae } \\
6797^{\mathrm{T}}\end{array}$ & $\begin{array}{c}\text { H. occidentalis } \\
6798^{\mathrm{T}}\end{array}$ & $\begin{array}{l}\text { K. lindneri } \\
7132^{\mathrm{T}}\end{array}$ \\
\hline 3062 & $\mathrm{G}$ & $\mathrm{G} / \mathrm{U}$ & 16 & 98 & 30 & 2 & 3 & 19 & 0 \\
\hline 3094 & $\mathrm{U}$ & $\mathrm{G} / \mathrm{U}$ & 98 & 35 & 16 & 7 & 22 & 21 & 0 \\
\hline 3096 & Os/U & $\mathrm{Os} / \mathrm{Vi}$ & 5 & 24 & 14 & 36 & 89 & 42 & 0 \\
\hline 3272 & $\mathrm{U}$ & $\mathrm{G} / \mathrm{U}$ & 92 & 35 & 11 & 2 & 0 & 12 & 0 \\
\hline 3280 & $\mathrm{U}$ & $\mathrm{G} / \mathrm{U}$ & 86 & 30 & 10 & 4 & 17 & 22 & 0 \\
\hline 3298 & Os & $\mathrm{Os} / \mathrm{Vi}$ & 6 & 26 & 7 & 3 & 93 & 42 & 0 \\
\hline 3447 & $\mathrm{U}$ & $\mathrm{G} / \mathrm{U}$ & 84 & 27 & 32 & 0 & 0 & 26 & 0 \\
\hline 3539 & $\mathrm{U}$ & $\mathrm{G} / \mathrm{U}$ & 98 & 33 & 40 & 2 & 10 & 25 & 0 \\
\hline 3542 & $\mathrm{U}$ & $\mathrm{G} / \mathrm{U}$ & 88 & 31 & 37 & 9 & 12 & 18 & 0 \\
\hline 3543 & Os & $\mathrm{Os} / \mathrm{Vi}$ & 13 & 20 & 20 & 97 & 20 & 27 & 0 \\
\hline 3582 & $\mathrm{U}$ & $\mathrm{G} / \mathrm{U}$ & 88 & 21 & 9 & 5 & 15 & 28 & 0 \\
\hline 4033 & Os & $\mathrm{Os} / \mathrm{Vi}$ & 19 & 20 & 17 & 77 & 32 & 28 & 0 \\
\hline 4059 & Os/U & $\mathrm{Os} / \mathrm{Vi}$ & 7 & 25 & 12 & 74 & 37 & 30 & 0 \\
\hline 4159 & $\mathrm{G} / \mathrm{Vi}$ & $\mathrm{Os} / \mathrm{Vi}$ & 11 & 18 & 17 & 85 & 30 & 25 & 0 \\
\hline 4160 & Os & $\mathrm{Os} / \mathrm{Vi}$ & 6 & 19 & 10 & 3 & 98 & 28 & 0 \\
\hline 4351 & $\mathrm{U}$ & $\mathrm{G} / \mathrm{U}$ & 97 & 33 & 28 & 2 & 5 & 12 & 0 \\
\hline
\end{tabular}

possible to assign any strain to a single species on the basis of PFGE. As in the case of the type strains, the profiles of those cultures originally designated as Hanseniaspora apuliensis or Kloeckera apiculata corresponded to those of the Hanseniaspora guilliermondiiHanseniaspora uvarum group (Fig. 2), whereas those classified as Kloeckera africana or Kloeckera magna were similar to both Hanseniaspora osmophila and Hanseniaspora vineae (Fig. 3). As a consequence, those strains with karyotypes similar to the species pairs Hanseniaspora guilliermondii/Hanseniaspora uvarum or Hanseniaspora osmophila/Hanseniaspora vineae had to be assigned a double 'CHEF phenotype' (Table 2).

In spite of these limitations, the electrophoretic karyotypes observed for those strains that gave unexpected physiological reactions (Figs 2 and 3, Table 2) consistently showed high similarities to those of the species to which they were originally assigned, rather than confirming the 'apparent phenotype' deduced from the physiological reactions performed in this study. This could therefore confirm the observations that phenotypic results can change as a result of genomic mutations caused during prolonged maintenance in culture collections where low-temperature conservation techniques are not employed (Scheda \& Yarrow, 1966, 1968; Stahl \& Esser, 1979a, b; Kirsop \& Kurtzman, 1988).

\section{DNA-DNA reassociation}

As a validation of the non-radioactive dot-blot hybridization method used in this study, our results were compared to those obtained in previous investigations (Smith et al., 1977; Meyer et al., 1978), which employed the radioactive membrane filter technique (Denhardt, 1966). As seen in Table 3, there was good agreement between the results of this and the earlier studies. The only exceptions were seen for Hanseniaspora vineae $\left(6797^{\mathrm{T}}\right)$ and the type strains of Hanseniaspora osmophila $\left(6791^{\mathrm{T}}\right.$ and $\left.6795^{\mathrm{T}}\right)$, where the percentage homology observed in this study was less than half that observed by Meyer and coworkers (23 and 18 as opposed to 56 and $60 \%$ ).

The results of the DNA-DNA hybridization experiments between the DBVPG strains and all type strains (Table 4) partially confirmed the phenotypes established on the basis of physiological and/or CHEF data (Table 2). In particular, when chromosomal profiles alone were considered, strains with a double ' $\mathrm{CHEF}$ phenotype' proved to be highly related (74-100\%) to only one of the two species, while showing significantly lower or no DNA reassociation with any other strain (values normally below $40 \%$ ).

The results of this investigation also find confirmation in two studies that compared the 26S rDNA sequences of apiculate yeasts (Yamada et al., 1992a; Boekhout et al., 1994), where a clear separation of all currently accepted species of Hanseniaspora Smith as well as of Kloeckera lindneri was shown. Interestingly, those species that, according to Boekhout et al. (1994), have the closest affinities (expressed as numbers of differences in the D1/D2 region of the large subunit of rDNA) were also those that showed identical karyo- 
types (Figs 1-3). Hanseniaspora guilliermondii and Hanseniaspora uvarum differ by six nucleotides, while Hanseniaspora osmophila and Hanseniaspora vineae show seven differences. On the contrary, differences above nine nucleotides, as seen between Hanseniaspora valbyensis and Kloeckera lindneri, corresponded to significantly different chromosomal patterns. A similar situation exists within the genus Saccharomyces, where the strains involved in alcoholic fermentation (the sensu stricto complex) have both very similar electrophoretic karyotypes (Cardinali \& Martini, 1994) and the closest intrageneric relationships as seen by the extent of nucleotide substitutions in rRNA sequences (Kurtzman \& Robnett, 1991).

Yamada et al. (1992b) proposed the division of the genus Hanseniaspora on the basis of partial rRNA sequences and other phenotypic differences. Hanseniaspora valbyensis, Hanseniaspora guilliermondii and Hanseniaspora uvarum would be maintained, while the genus Kloeckeraspora (Janke, 1928) would be revived for Hanseniaspora occidentalis, Hanseniaspora osmophila and Hanseniaspora vineae (Yamada et al., 1992b). Although they recognized a certain distance between these two groups of species, Boekhout et al. (1994) did not agree with this modification in the light of the intraspecific variability present within these groups. According to those authors, a division could introduce too much confusion for species distinction based upon phenotypic criteria. In view of the variations in physiological profiles observed in this study, we also disagree with excessive generic separations. Finally, the unity of the genus Hanseniaspora was confirmed in an extensive comparison of the rDNA large subunit D1/D2 domains of over 500 currently accepted yeast species (Kurtzman \& Robnett, 1998). In this latter investigation, it was shown that species of Hanseniaspora, together with Kloeckera lindneri, form a distinct subclade within the Saccharomyces clade.

\section{ACKNOWLEDGEMENTS}

This study was partially financed by a grant from the Italian Council for Research (CNR) [CNR-Progetto Strategico Biodiversità. Unità Operativa Diversità di microrganismi in ambiente agroambientale-alimentare: Indagini microbiologiche mirate agli ambienti di produzione dei vini italiani (AEV-M)] and by a contribution from the Italian Ministry for Research and Education [Progetti d'Ateneo (ex MURST $60 \%$ ): Sistemi riproduttivi negli organismi d'interesse agrario: Applicazioni biotecnologiche in Poa pratensis e Saccharomyces cerevisiae (GLC)].

\section{REFERENCES}

Beijerinck, M. W. (1898). Über Regeneration der Sporenbildung bei Alkoholhefen wo diese Funktion im Verschwinden begriffen ist. Zentbl Bakteriol Parasitenkd 4, 657-663; 721-730.

Boekhout, T., Kurtzman, C. P., O’Donnell, K. \& Smith, M. T. (1994). Phylogeny of the yeast genera Hanseniaspora (anamorph Kloeckera), Dekkera (anamorph Brettanomyces), and Eeniella as inferred from partial $26 \mathrm{~S}$ ribosomal DNA nucleotide sequences. Int J Syst Bacteriol 44, 781-786.
Cardinali, G. \& Martini, A. (1994). Electrophoretic karyotypes of authentic strains of the sensu stricto group of the genus Saccharomyces. Int J Syst Bacteriol 44, 791-797.

Cardinali, G., Pellegrini, L. \& Martini, A. (1995). Improvement of chromosomal DNA extraction from different yeast species by analysis of single preparation steps. Yeast 11, 1027-1029.

Cardinali, G., Liti, G. \& Martini, A. (2000). Non-radioactive dotblot DNA reassociation for unequivocal yeast identification. Int J Syst Evol Microbiol 50, 931-936.

Denhardt, D. T. (1966). A membrane-filter technique for the detection of complementary DNA. Biochem Biophys Res Commun 23, 641-646.

James, S. A., Cai, J., Roberts, U. N. \& Collins, M. D. (1997). A phylogenetic analysis of the genus Saccharomyces based on 18S rRNA gene sequences: description of Saccharomyces kunashirensis sp. nov. and Saccharomyces martiniae sp. nov. Int $J$ Syst Bacteriol 47, 453-460.

Janke, A. (1928). Über die Formgattung Kloeckera Janke. Zentbl Bakteriol Parasitenk 76, 161.

Kirsop, B. E. \& Kurtzman, C. P. (editors) (1988). Living Resources for Biotechnology. Cambridge: Cambridge University Press.

Klöcker, A. (1912). Beschreibungen von 17 Saccharomyces apiculatus Formen. Zentbl Bakteriol Parasitenkd 35, 375-388.

Kurtzman, C. P. \& Phaff, H. J. (1987). Molecular taxonomy. In The Yeasts: Biology of Yeasts, vol. 1, pp. 63-94. Edited by A. H. Rose \& A. J. S. Harrison. London: Academic Press.

Kurtzman, C. P. \& Robnett, C. J. (1991). Phylogenetic relationships among species of Saccharomyces, Schizosaccharomyces, Debaryomyces and Schwanniomyces determined from partial ribosomal RNA sequences. Yeast 7, 61-72.

Kurtzman, C. P. \& Robnett, C. J. (1998). Identification and phylogeny of ascomycetous yeasts from analysis of nuclear large subunit (26S) ribosomal DNA partial sequences. Antonie Leeuwenhoek 73, 331-371.

Lindner, P. (1903). Sporenbildung bei Saccharomyces apiculatus. Wock schr Brau 20, 505-506.

Lodder, J. \& Kreger-van Rij, N. J. W. (1952). The Yeasts: a Taxonomic Study. Amsterdam: North-Holland.

Meyer, S. A., Brown, R. E. \& Smith, M. T. (1977). Species status of Hanseniaspora guilliermondii Pijper. Int J Syst Bacteriol 27, 162-164.

Meyer, S. A., Smith, M. T. \& Simione, F. P., Jr (1978). Systematics of Hanseniaspora Zikes and Kloeckera Janke. Antonie Leeuwenhoek 44, 79-96.

Phaff, H. J. (1970). Hanseniaspora Zikes. In The Yeasts: a Taxonomic Study, 2nd edn, pp. 209-225. Edited by J. Lodder. Amsterdam: North-Holland.

Phaff, H. J. (1989). Trends in yeast systematics. In Proceedings of the 7th International Symposium on Yeasts, Perugia, Italy, pp. S341-S349. Edited by A. Martini \& A. Vaughan-Martini. Chichester: Wiley.

Price, C. W., Fuson, G. B. \& Phaff, H. J. (1978). Genome comparison in yeast systematics: delimitation of species within the genera Schwanniomyces, Saccharomyces, Debaryomyces, and Pichia. Microbiol Rev 42, 161-193.

Reess, M. (1870). Botanische Untersuchungen über die Alkoholgährungspilze. Leipzig: A. Felix.

Scheda, R. \& Yarrow, D. (1966). The instability of physiological properties used as criteria in the taxonomy of yeasts. Arch Mikrobiol 55, 209-225.

Scheda, R. \& Yarrow, D. (1968). Variation in the fermentative 
pattern of some Saccharomyces species. Arch Mikrobiol 61, 310-316.

Smith, M. T. (1998a). Hanseniaspora Zikes. In The Yeasts: a Taxonomic Study, 4th edn, pp. 214-220. Edited by C. P. Kurtzman \& J. W. Fell. Amsterdam: Elsevier.

Smith, M. T. (1998b). Kloeckera Janke. In The Yeasts: a Taxonomic Study, 4th edn, pp. 580-581. Edited by C. P. Kurtzman \& J. W. Fell. Amsterdam: Elsevier.

Smith, M. T., Simione, F. P., Jr \& Meyer, S. A. (1977). Kloeckera apis sp. nov.; the imperfect state of Hanseniaspora guilliermondii Pijper. Antonie Leeuwenhoek 43, 219-223.

Stahl, U. \& Esser, K. (1979a). Inconsistency in the species concept for yeasts due to mutations during vegetative growth. Eur $J$ Appl Microbiol Biotechnol 8, 271-278.

Stahl, U. \& Esser, K. (1979b). Subsequent transfers of yeast may lead via single gene mutations to alterations of the species. Biotechnol Lett 1, 383-385.

Vaughan-Martini, A., Martini, A. \& Cardinali, G. (1993). Electrophoretic karyotyping as a taxonomic tool in the genus $\mathrm{Sac}$ charomyces. Antonie Leeuwenhoek 63, 145-156.
Vaughan-Martini, A., Pollacci, P. \& Barcaccia, S. (1999). A reconsideration of species designations of some strains of the Industrial Yeasts Collection DBVPG assigned to the genus Torulaspora. Ann Microbiol Enzimol 49, 67-77.

Yamada, Y., Maeda, K. \& Banno, I. (1992a). The phylogenetic relationships of the Q6-equipped species of the teleomorphic apiculate yeast genera Hanseniaspora, Nadsonia and Saccharomycodes based on the partial sequences of $18 \mathrm{~S}$ and $26 \mathrm{~S}$ ribosomal ribonucleic acids. J Gen Appl Microbiol 38, 585-596.

Yamada, Y., Maeda, K. \& Mikata, K. (1992b). An emendation of Kloeckeraspora Niehaus with the type species, Kloeckeraspora osmophila and the proposals of two new combinations, Kloeckeraspora occidentalis and Kloeckeraspora vineae (Saccharomycetaceae). Bull Jpn Fed Cult Collect 8, 79-85.

Yarrow, D. (1998). Methods for the isolation, maintenance and identification of yeasts. In The Yeasts: a Taxonomic Study, 4th edn, pp. 77-100. Edited by C. P. Kurtzman \& J. W. Fell. Amsterdam: Elsevier.

Zikes, H. (1911). Zur Nomenclaturfrage der Apiculatshefe. Zentbl Bakteriol Parasitenk 30, 145-149. 